\title{
TAXATION OF UNREALIZED GAINS AT DEATH-AN EVALUATION OF THE CURRENT PROPOSALS
}

\author{
Micbael J. Graetz*
}

\section{INTRODUCTION}

THE failure to tax the appreciation of capital assets transferred at death has been described as the major shortcoming of existing federal income tax laws. ${ }^{1}$ From time to time since 1942, the Department of the Treasury and others have urged alteration of the rule which underlies this failure. ${ }^{2}$ Recently the House Ways and Means Committee held panel discussions and public hearings on the subject of tax reform during which consideration was given to the possibility of changing the laws dealing with taxation of appreciated property at death. In its recommendations to the Committee, the Treasury Department did not push for change in this area. ${ }^{3}$ Nevertheless, Congress seems likely to approve some revision of the present rules allowing a stepped-up basis of assets transferred at death. ${ }^{4}$ This Article evaluates the leading proposals for

* Assistant Professor of Law, University of Virginia. B.B.A., 1966, Emory University; L.L.B., 1969, University of Virginia; Staff of the Assistant Secretary for Tax Policy, Department of the Treasury, 1969-1972. This article is based on testimony by the author concerning estate and gift tax reform before the House Committee on Ways and Means, on March 27, 1973.

1 See, e.g., Kurtz, \& Surrey, Reform of Death and Gift Taxes: The 1969 Treasury Proposals, The Criticisms, and a Rebuttal, 70 Colum. L. Rev. 1365, 1381 (1970).

2 In 1942, the Treasury recommended that a beneficiary carry over the decedent's basis in property transferred at death. See Hearings on Revenue Revision of 1942 Before the House Comm. on Ways and Means, 77th Cong., 2d Sess., vol. 1, at 89 (1942) (statement of Randolph Paul). In 1963, President Kennedy proposed taxation of unrealized gains at death. Hearings on President's 1963 Tax Message Before the House Comm. on Ways and Means, 88th Cong., 2d Sess. 20, 49, 122 (1963). Neither of these proposals was adopted by the Congress.

3 See U.S. Dep't of the Treasury, Proposals for Tax Change at 74-76 (1973).

4 The House Ways and Means Committee held panel discussions and public hearings on tax reform from February 5, 1973 to April 30, 1973. Chairman Wilbur D. Mills has indicated that he expects a tax reform bill to be passed by the House of Representatives during the fall of 1973. For the purposes of simphicity the discussion in this Article assumes that the present system for taxing capital gains and other provisions of the tax law will remain essentially unchanged by the Congress. However, Chairman Mills has indicated that he favors basic changes in the taxation of capital gains, for example, by pro viding for a variation of the rate of tax which would depend upon how long an asset 
change in this area by examining the way each proposal treats ten specific problems which arise in conjunction with transfers of appreciated property at death and makes recommendations concerning possible solutions to the problems.

\section{Current Law}

Under present law beneficiaries of an estate receiving appreciated property are permitted to use, in place of the decedent's basis, a new or "stepped-up" basis in that property for the purposes of calculating federal income tax. This new basis is equal to the value of the property for estate tax purposes or, in other words, the fair market value of the property on the date of the decedent's death. ${ }^{5}$ The decedent's basis would typically have been the price at which the decedent originally acquired the property, which is often considerably lower than the value of the property at his death. If the beneficiary later sells the property, his tax will take into account only the gain or loss above or below its estate tax value, and the appreciation of the property over the decedent's lifetime escapes income tax. In contrast, had the decedent sold the property before his death, the appreciation in value of that property which occurred during his lifetime would have been subject to income tax at the time of sale. Moreover, had the decedent made a gift of the property prior to death, the donee would not have been given a stepped-up basis for the purposes of income tax but would have been deemed to have taken the property with the donor's basis; any gain which had accrued while the donor held the property would be taxed when the donee sold the property. ${ }^{6}$

\section{The Proposals for Change}

Proponents of change have suggested two general plans to eliminate the present failure to tax the appreciation of assets transferred at death: (1) a tax on the appreciation accrued up until the time of death, even though it remains unrealized, or (2) a requirement that the de-

is held. Changes of this magnitude might require modifications of some of the specific recommendations of the author. See generally Panel Discussions on General Tax Reform Before the House Comm. on Ways and Means, 93d Cong., 1st Sess. (1973); Hearings on General Tax Reform Before the House Comm. on Ways and Means, 93d Cong., 1st Sess. (1973).

5 See INT. REv. CoDE of 1954, $\$ 1014$. In some cases the value as of an alternative date six months after the decedent's death is used.

6 INT. REv. CoDE of $1954, \S 1015$. 
cedent's basis be carried over, so that the total appreciation is taxed when the asset is eventually sold. ${ }^{7}$

There are two proposals for taxing unrealized gains at death. First, a capital gains tax on unrealized appreciation may be imposed whenever property is transferred at death. The leading deathtime capital gains tax proposal was detailed in the Treasury Tax Reform Studies published in February, $1969,{ }^{8}$ and two statutory versions of the proposal have been introduced in the Congress. ${ }^{9}$ Second, an "additional estate tax" (AET) may be levied on the unrealized appreciation passing with the estate. The AET scheme, proposed by the American Bankers Association $(\mathrm{ABA})$, would levy a tax at a flat rate above and beyond the existing estate tax and would apply to the net appreciation of a decedent's assets transferred at death or within two years prior to death. ${ }^{10}$

The carryover basis proposals, on the other hand, generally provide that the beneficiary's basis in property transferred at death will be equal to the decedent's basis in the property immediately prior to his death. Several carryover basis bills have been recently introduced in Congress, including three similar House bills ${ }^{11}$ and an amendment offered by Senator Tydings to the Tax Reform Act of $1969 . .^{12}$ While the general thrust of the bills is the same, the details of the House and Senate bills differ significantly.

\section{THE NEED FOR REFORM}

A tax on unrealized appreciation accruing during the decedent's lifetime would produce three benefits: greater equity, reduction of the "lock-in" effect, and additional revenue. ${ }^{13}$

7 Much of the debate over change in the present stepped-up basis rules has centered around the economic question whether accrued but unrealized gains are income. Compare Shoup, The Wbite Paper: Accrual Accounting for Capital Gains and Losses, 18 CaN. Tax J. 96 (1970) with D. Smith, Federal TAx ReForm 120-21 (1961).

8 See generally U.S. Dep't of the Treasury, Tax Reform Studies and Proposals, 91st Cong., 1st Sess., pt. 3 at 331-34 (1969) [hereinafter cited as Treasury Proposals].

9 S. 3378, 92nd Cong., 2d Sess. $\$ 113$ (1972); H. R. 8757, 92d Cong., 1st Sess. (1971).

10 The AET proposal is detailed in Covey, Possible Changes in the Basis Rule for Property Transferred by Gift or at Death, 50 Taxes 831 (1972) [hereinafter cited as Covey]. This description of the proposal is the basis for the textual discussion in this Article.

11 H. R. 13857, 92d Cong., 2d Sess. (1972); H. R. 11058, 92d Cong., 1st Sess. $\$ 113$ (1971); H. R. 5250, 91st Cong, 1st Sess. (1969).

12 H. R. 13270, (Senate amend. No. 333) 91st Cong, 1st Sess. (1969), reprinted in 115 CONG. REC. 37305-06 (1969).

13 See Treasury Proposals, supra note 8, at 331-34. 


\section{Equity}

Commentators have long criticized as inequitable the present practice of leaving untaxed those estates composed of unrealized appreciation while taxing appreciation when assets are sold prior to death. The significance of this practice can be illustrated by comparing two individuals:

-A started with $\$ 1,000,000$ of property which produced no income but rose in value $\$ 1,000,000$ during his lifetime. The day before his death he sold the property. He paid a capital gains tax of $\$ 350,000$, leaving an estate of $\$ 1,650,000$.

-B started with $\$ 1,000,000$ of property which produced no income but rose in value $\$ 1,000,000$ during his lifetime. He died holding the property, leaving a $\$ 2,000,000$ estate.

A paid a capital gains tax on the appreciation and his estate will pay an estate tax on the balance. B's estate will pay only an estate tax. Assuming a marginal estate tax rate of 45 percent on each estate, A's beneficiaries will receive $\$ 907,500$; B's beneficiaries will receive $\$ 1,100,000$.

The Treasury deathtime capital gains tax proposal treats $B$ as if he too had realized his gain before death. Thus, a capital gains tax would apply to the unrealized appreciation of assets held at death. To avoid double taxation, the Treasury proposal allows the amount of capital gains tax actually paid to be deducted from the value of the estate for estate tax purposes. The proposal is based on two premises: that unrealized gains are income, and that while it may not be administratively feasible because of the complexity of valuation to tax such unrealized gains as they accrue, it is appropriate to tax them at death.

The carryover basis proposals treat dispositions at death more like liketime gifts than sales. They thus adopt rules similar to current gift tax law which provides that the donee assumes the donor's basis in the asset. While the decedent's estate still must pay an estate tax, the payment of an income tax is deferred until the beneficiary actually realizes a gain by selling the asset. To avoid the problem of double-taxation in this context, the proposals provide that the basis of the asset be adjusted upward by a specified portion of the estate tax paid on it. This adjustment would reduce substantially the amount of gain which is recognized for the purposes of computing federal income tax to insure that the tax 
burden is the same regardless of whether the income or estate tax is imposed first. ${ }^{14}$

Both the House and Senate carryover basis bills provide a basis adjustment, but whereas the Senate bill follows the current rule for lifetime gifts and allows an increase in basis for the full amount of the federal and state estate taxes levied on the asset, ${ }^{15}$ the House bill allows an increase of the basis only in the proportion that estate taxes were levied upon the asset's net appreciation. Since only the appreciation element would be subject to both income and estate taxes, the basis increase of the House bill is proper. Regardless of the method used, the practical application of this basis adjustment would be quite complex..$^{16}$

To avoid the complexity of a basis adjustment, the ABA additional estate tax proposal includes no adjustment even though the estate tax

14 One way to view the need for a basis adjustment is to say that the estate tax is overpaid by an amount equal to the income tax on capital gains which will subsequently have to be paid by the transferee, i.e., that the value of the estate for estate tax purposes should have been reduced by the income tax which would thereafter be paid on the appreciation element of the gross estate. Adding a portion of the estate tax to basis results in a reduction in income tax to offset the overpayment of estate taxes.

The total tax on $B$ in the example cited in the text ( $B$ bequeaths appreciated assets to his heirs) will be roughly equal to the tax on $A$ (who sells appreciated assets during life and pays capital gains tax) only if the estate tax savings of $\mathrm{A}$, caused by a reduction of his gross estate due to the capital gains tax paid at the time of sale, equals the income tax savings of $B$ which would be achieved by the basis adjusting procedures.

Furthermore, the addition to basis will afford equality only if the income tax bracket of the heirs is the same as the income tax bracket of the decedent (if he sells the property) and if the estate tax attributable only to the appreciation element of the property is added to basis. This may be illustrated by the following formula:

Let the estate tax rate equal RE, the income tax rate equal RI, the appreciation element of the property equal A. Then the overpayment of estate tax due to the income tax liability (or the savings in estate tax, if the property were sold prior to death) equals $\mathrm{RE}$ times $\mathrm{RI}(\mathrm{A})$. If the estate tax attributable to the appreciation element ( $R E(A)$ ) is added to basis, the income tax savings will equal RI times $\mathrm{RE}(\mathrm{A})$, i.e., the income tax saved will equal the estate tax overpaid.

15 See H.R. 13270, (Senate amend. No. 333) 91st Cong., 1st Sess. (1969), reprinted in 115 Cong. Rec. 37305-06 (1969).

$16 \mathrm{~A}$ determination of the estate tax attributable to the appreciation element of specific properties will be required; this could be accomplished by a pro rata allocation or by precise tracing. No basis increase should be provided for properties passing to the surviving spouse or charity free of estate tax, and this complicates the basis of adjustment. The portion of estate tax to be added to the basis of property subject to the estate tax could be determined by computing the total estate tax burden on the net appreciation of all properties (the higlrest marginal rates seem most correct conceptually for this determination) and then allocating such amount to a particular property in the ratio that the appreciation element of such property bears to the total appreciation (gross) of all property. 
is applied prior to the tax on appreciation. The ABA acknowledges that this rule results in double taxation and even admits that the "logical way of avoiding this result in connection with the AET is to increase the basis of the decedent's property by the estate tax attributable to the net appreciation before imposition of the AET." However, the Association has refused to adopt such basis adjusting procedures, arguing that they are "regressive." 17 The ABA, in its search for simplicity, has thus introduced a new inequity: double taxation. Moreover, the argument that the Association has advanced to justify the AET tax scheme is clearly specious. In claiming that basis adjusting is regressive, the ABA has argued essentially that tax savings which would result from such adjustments would be proportionately greater for large estates than for smaller estates. ${ }^{18}$ But if the ABA's line of reasoning were used, many deductions necessary to determine the taxable estate could be labelled "regressive." For example, the exclusion from the estate of the capital gains and income taxes paid during lifetime, or the allowance of a deduction from the estate for funeral or administrative expenses could both be dubbed "regressive," but it is doubtful that the ABA or any other organization would advocate that these deductions be eliminated. That such provisions do more to lessen the tax burden among higher bracket than lower bracket taxpayers is simply a characteristic of a graduated rate schedule. ${ }^{10}$ If the $\mathrm{ABA}$ is concerned about the impact which a tax on appreciation, in conjunction with the present estate tax, will have on medium and smaller sized estates, the proper remedy is to revise the estate tax rules to produce the desired progressivity, not to tax the appreciation twice.

In summary, the Treasury capital gains tax proposal, the AET and the carryover basis bills generally redress the inequity of present law, but whereas the Treasury and AET schemes contemplate levying a tax on capital gains at the time of death, the carryover basis approach substantially defers the imposition of the tax. However, the flat rate AET proposal introduces a new inequity-cloaked in rhetoric of regressivity-rather than accept the complexity of a basis adjustment.

17 Covey, supra note 10 , at 845 .

18 For unknown reasons, the $\mathrm{ABA}$ did not raise similar objections to the basis adjustment under the House carryover basis bill. See Covey, supra note 10 , at 838 .

19 For example, if a wealthy man in a 70 percent bracket loses $\$ 1000$ of wages the Government absorbs $\$ 700$ of the loss, but in the case of a 30 percent taxpayer, the Government absorbs only $\$ 300$. 


\section{Lock-in Effect}

A second argument made for changing the capital gains tax is based on the contention that owners of appreciated property, aware of the stepped-up basis to be given to the beneficiaries of their estate, commonly refuse to sell such property prior to death and thereby "lock-in" assets that would otherwise be traded in the marketplace. This "lockin" effect is thought undesirable as it reflects an artificially induced decision not to trade, and is therefore a distortion of a normal capital flow. ${ }^{20}$ Clearly the current system does influence certain taxpayers to hold until death greatly appreciated assets which they might otherwise sell during life. However, none of the outstanding proposals will eliminate this "lock-in" effect. Moreover, because the deleterious economic effects of "lock-in" are unclear, it is questionable whether an effort to avoid this problem is worth the increased complexity it would entail.

This is particularly true since any provisions designed to mitigate the effect of a deathtime tax will reinforce "lock-in." For example, the Treasury proposal will perpetuate some "lock-in" effect since it contains provisions exempting from deathtime capital gains tax small estates (under $\$ 60,000)$ which are not subject to the estate tax, and transfers of appreciated property to the surviving spouse. Further, it is generally conceded that the proposal will not apply the minimum tax on tax preferences to deathtime gains ${ }^{21}$ and will not contain the $\$ 50,000$ limit on the alternative capital gains tax which was introduced by the 1969 Tax Reform Act. ${ }^{22}$ Those aspects of the Treasury proposal would undoubtedly induce the same persons who hold assets until death under present law in order to take advantage of the stepped-up basis to continue to do so. Persons with small estates would hold assets until death to take advantage of the $\$ 60,000$ minimum basis at death; persons with very large estates

20 See, e.g., Panel Discussions on General Tax Reform Before the House Comm. on Ways and Means, 93d Cong., 1st Sess., pt. 2, at 340-41 (1973).

21 The minimum tax was enacted to levy some tax on high income individuals who otherwise pay little or no tax because of "tax preference" provisions. Since unrealized appreciation at death is not presently considered a "tax preference" although it completely escapes taxation, and in view of the fact that in its recent testimony presenting recommendations for total revision of the minimum tax the Treasury Department did not include unrealized appreciation in its revised list of tax preferences, it is unlikely that the minimum tax provisions would apply to this appreciation if and when it is taxed. See Department of the Treasury, Proposals for Tax Change 9-14 (1973).

22 Prior to the 1969 Act the alternative tax provided a maximum rate of 25 percent on all capital gains. The 1969 Act limited this 25 percent maximum rate to the first $\$ 50,000$ of capital gaius. The new provision allows a tax on capital gains which is considerably in excess of 25 percent. 
would hold until death in order to take advantage of the 25 percent maximum rate on capital gains and avoid imposition of the minimum tax on tax preferences, or to postpone the tax completely by transferring the assets to a spouse. Moreover, as a result of the 1969 provision creating a 50 percent maximum tax on earned income, persons with large amounts of earned income will prefer to hold capital assets until death because realization of lifetime capital gains will reduce earned income subject to the maximum 50 percent rate. ${ }^{23}$

Although the ABA proposal, like the Treasury proposal will not solve the "lock-in" problem, either plan will reduce the tax benefits of holding assets until death. The carryover basis plans, on the other hand, may actually amplify the "lock-in" effect. Once an untaxed asset passes to the beneficiary he will be particularly reluctant to sell since he would have to pay tax on the gain that accrued during the decedent's lifetime. ${ }^{24}$

\section{Revenue}

Increasing the federal fisc is a third reason for reform. Taxing unrealized gains at death could produce an estimated $\$ 1.5$ to $\$ 4$ billion in additional revenue annually, depending on the rate of tax and the exemptions. $^{25}$ The ABA and Treasury proposals would use this revenue to reduce estate and gift taxes. ${ }^{26}$ Alternatively, the revenue could be used to reduce income taxes, to reduce the deficit, or to finance additional government spending. Since both these proposals would exempt gains which accrued prior to enactment of the deathtime tax, the additional annual revenue would not reach its full potential for many years.

The revenue gain from implementing a carryover basis law is difficult to predict since such revenue will be realized only when assets are sold by beneficiaries or by the decedent's estate. However, estimates of the long-run annual revenue to be realized by a change to carryover basis

23 INT. Rev. CoDE of 1954, § 1348.

24 Two alternatives for solving the "lock-in" problem are available: (1) provide a disincentive to holding assets until death by imposing higher rates on unreahzed appreciation at death than on lifetime dispositions-taxing deathtime appreciation at ordinary income rates has been suggested; (2) provide an incentive to lifetime dispositions through lower rates or by a credit against the estate tax for lifetime capital gains taxes paid. However, distortions in capital flows would also be produced by provisions such as these, and it is unclear whether they would be an improvement over either the Treasury or ABA proposals for taxing unrealized appreciation at death.

25 See Graetz, Reflections on the Tax Legislative Process: Prelude to Reform, 58 VA. L. REv. 1389, 1416 (1972).

26 Treasury Proposals, supra note 8, at 335, 341; Covey, supra note 10, at 832, 836. 
are generally about $\$ 600$ million. Thus, any estate or income tax reduction would apparently be much less substantial under a carryover basis plan than under a plan which imposes a tax at death.

\section{The Complexity of Reform}

The principal disadvantage of change is that the new law is likely to be considerably more complex than present law. Although the existing law which provides a step-up of basis without tax on unrealized gains is inequitable, it is quite simple. In contrast, the Treasury proposal, which attempts to achieve rather precise equity, is unduly complex. Similarly, the other reform proposals fail to achieve the proper blend of equity and simplicity. In evaluating and choosing among the different proposals for change, Congress must inevitably strike a balance between such potential complexity and the anticipated improvement in tax equity. The choice between equity and simplicity is like the economist's classic choice between guns and butter; to get more of one, it is necessary to sacrifice some of the other. At one end of the sliding scale, we can achieve almost total equity by completely sacrificing simplicity. It is only when the tax laws become somewhat less equitable that complexity reaches manageable proportions. There are many provisions within the present tax structure which reflect this compromise between equity and simplicity. ${ }^{27}$ But just as in the guns and butter choice, there is no guiding principle which determines the optimum point on the scale.

Replacing the stepped-up basis treatment of capital assets will increase complexity in two ways. First, each of the reform proposals would require a determination of the basis of a capital asset either in the decedent's hands or as of a new valuation date. Either determination will prolong the time necessary to resolve the tax liabilities of an estate. This factor runs counter to a major policy of the 1970 legislation, ${ }^{28}$ which attempted to shorten the time necessary to administer estates, and will of course increase the costs of administering estates. Second, the proposals will involve the completion of additional forms, compilation of records concerning the decedent's basis and date of acquisition, the need to correspond with beneficiaries, and the contestation of additional issues, all of which will add substantially to the time and cost of administering estates.

27 For one discussion of the compromise see Surrey \& Brannon, Simplification and Equity as Goals of Tax Policy, 9 WM. \& MARY L. Rev. 9I5 (1968).

28 H. R. Rep. No. 91-1635, 91st Cong., 2d Sess. 4-13 (1970). 


\section{Basis Determination under Specific Proposals}

Of the four proposals, those which advance a carryover basis seem to involve more inherent complexity than those which call for a tax on appreciation at death. This is true because the carryover proposals require not only determination of the basis of transferred assets but also maintainance of records of basis over several generations. The carryover basis proposals generally attempt to lessen the impact of these requirements by compelling the executor, in administering the estate, to file sufficient information to enable the beneficiaries of the estate and the Internal Revenue Service (IRS) to determine the basis of assets contained in the estate. But it is not clear whether such information would be binding upon the beneficiary or the IRS. Clearly the IRS would not be precluded from alleging a lower basis than that shown on the information return. Conversely the beneficiary, if he could show that the decedent had a higher basis than was reported to the IRS by the executor, should not be bound by the executor's return.

While the basis problem cannot be eliminated completely, a provision removing the IRS from any controversy at an early stage would be desirable. One possibility under either a carryover basis or a deathtime tax proposal, would be to make the executor's determination of the basis of any asset, once audited, binding upon the IRS in subsequent tax computations on the asset. This would compel the IRS to audit the executor's determination of basis, ${ }^{29}$ and would require that the executor provide sufficient information relating to basis to make such a determination feasible. Where the decedent's basis cannot be determined, the basis should be deemed to be the fair market value of such property as of the approximate date on which the property was acquired by the decedent. ${ }^{30}$

Adjustments to basis under the carryover or AET proposals are another source of confusion. For example, property which passes to the surviving spouse or charity free of estate tax would not be subject to a basis adjustment, as would assets transferred to other persons, to account for estate taxes paid. This, in turn, requires distinction among assets according to their transferee, a process which may be exceedingly

29 Under the existing estate tax scheme the decedent's basis is irrelevant since the tax is calculated with reference to the estate's market value at the time of death.

30 Such an alternative is necessary because estates often have incomplete records which do not indicate the basis of certain assets in the hands of the decedent, and such incompleteness cannot be expected to be rectified. 
complex since the executor may not know for a substantial period of time precisely which assets are to pass to the spouse, to charity, or to other persons. Similar problems occur under the Treasury proposal because of a requirement that the total basis be allocated among all property, other than cash, before computing the taxable gain. Under a deathtime tax, basis allocation becomes an issue only when transfers to certain beneficiaries are exempt from tax. In using an allocated, as opposed to an actual basis, the Treasury hoped to eliminate the incentive under the proposed system of taxation to transfer property to persons such as the spouse or a charity who are exempt from capital gains tax in order to avoid paying the high tax on low-basis assets. If basis were allocated, there would be no incentive to give high-basis assets to children and low-basis assets to tax-exempt persons. ${ }^{31}$ However, in view of the significant complexities resulting from basis allocations ${ }^{32}$ and the absence in the past of a strong tax policy objective of curing this income tax "abuse," ${ }^{33}$ no allocation should be required under any deathtime tax on appreciation. Avoiding an allocation of basis is more difficult under a carryover basis rule since the income tax liability on all assets will still be undetermined at the time of transfer, and the assets will not have been given a new basis as they would after imposition of a deathtime tax.

These problems of determination, adjustment, and allocation of basis represent only a portion of the difficulty of reform. The determination of how much additional complexity will result from a change in the law depends primarily on the details of the bill. The following chart summarizes the four proposals' positions on ten significant issues:

31 The AET proposal avoids these problems by not exempting property passing to the spouse or charity. See text at notes 41,48 , infra.

32 The Treasury provision would be particularly complex when ordinary income assets as well as capital assets are transferred.

33 Under present law there is, even since the 1969 Act revisions were put into effect, an incentive to give low-basis assets to charity. See text at note 48 , infra. Since it was not deemed necessary to prevent this practice in the context of inter vivos transfers to charity under the 1969 Act, it does not seem necessary to alter it in the context of assets transferred at death.

In addition, it should be noted that the Treasury proposal, if logically extended, would require an allocation of the basis of all transferred assets, whether the transfer is inter-vivos or deathtime. Since all of the decedent's assets are generally disposed of 2t death, it is of course possible to allocate all basis at that time. However, it seems urilikely that any real abuses will-occur with respect to deathtime transfers of assets other than marketable securities. 

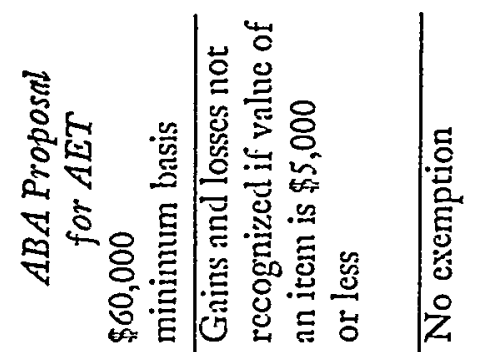

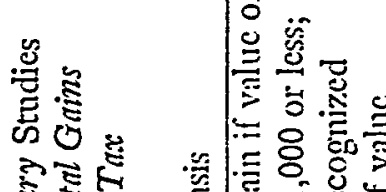

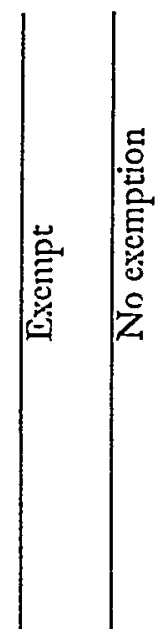

है

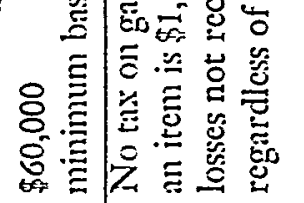

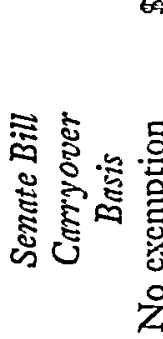

氞

Z

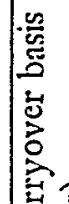

氞

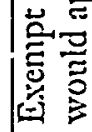

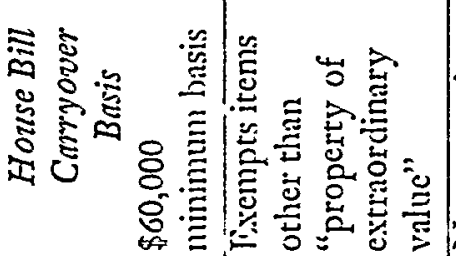

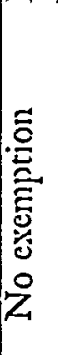

蒙 蒙

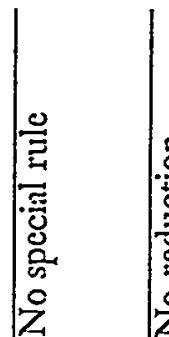

$\mid$

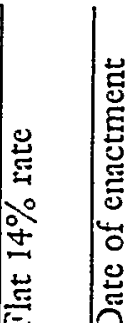

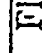

iิ 。

.

형

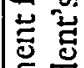

总总

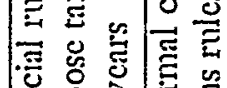

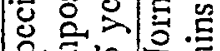

की. 正纪

至 总 导

焉 e 要

Е 至峲它

焉

造䓵

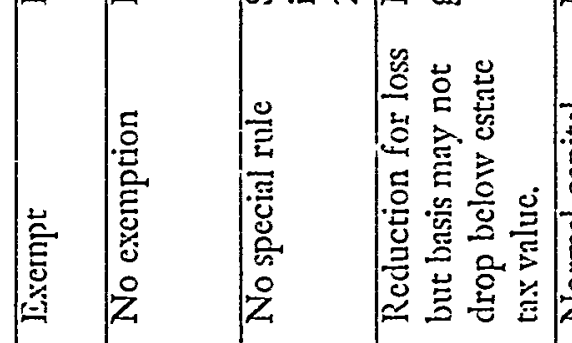

䍃

巳

䆠芯㤩

Z 畐保至

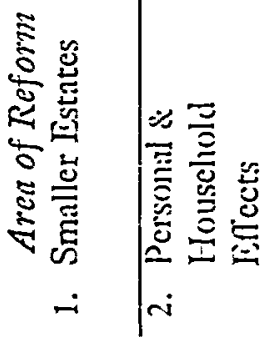

훌

z

|

웅요

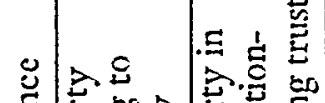

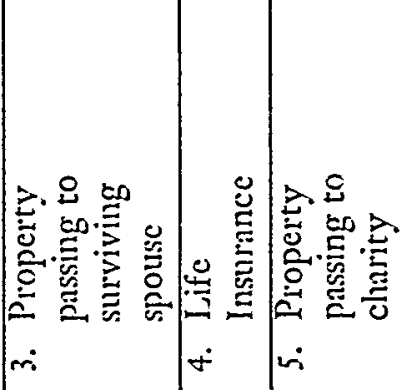

넌엔

苍岂

مَ

产

语

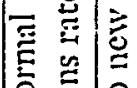

Z 
The following discussion will contrast these proposals with the British treatment of deathtime tax in appropriate areas. ${ }^{34}$

\section{Specific Areas of Reform}

\section{Exemption for small estates.}

The House carryover basis bill and the Treasury and AET proposals would apply only to gross estates of $\$ 60,000$ or more (because they provide a $\$ 60,000$ minimum basis for all estates); the stepped-up basis of present law would continue for gross estates which contained assets worth less than that threshold amount. Only the Senate carryover basis bill would not exempt gross estates of less than $\$ 60,000$. A $\$ 60,000$ minimum basis coinciding with the estate tax exemption amount, would significantly simplify administration since it would exempt 90-95 percent of those who die each year from the requirements of the new tax law. Such simplification seems desirable even though the inequity between lifetime and deathtime dispositions exists without regard to the size of the estate, and despite the fact that an estimated third to one-half of net appreciation transferred at death would be exempted under the provision, ${ }^{35}$ and that, as noted above, a minimum basis rule would help perpetuate the "lock-in" effect of present law.

Another possible way of dealing with smaller estates would be to exempt from taxation a specific portion of the capital gain contained in such estates. Until 1971 the British system of taxation exempted the first $£ 5000$ of gain and a decedent's personal residence from its deathtime capital gains tax. ${ }^{36}$ If, as in Britain, an exemption of a specified amount of gain is provided in conjunction with a new valuation date, most estates would owe no deathtime tax during the first few years after the new valuation date. This alternative, while permitting a gradual and orderly phase-in period, at least temporarily reduces the revenue benefits sought in reform. However, were the exemption for personal residences used in conjunction with such a gains exemption, some internal restrictions upon size of residence would be necessary to preclude

34 From 1965 to 1971 the British imposed a capital gains tax at death. The Conservative Government removed the tax in 1971, and the Labor Party, at that time, pledged to reverse that action when it returned to power. The author spent a week in Britain in January, 1971, discussing the British tax with officials of Inland Revenue, academicians and private practitioners. The textual discussion of the British system is based in large part on those discussions. See also Board of Inland Revenue, Capitat Gains Tax (1968) [hereinafter cited as CapitaI GaINs TAX].

35 See Treasury Proposals, supra note 8, at 331, 333.

36 Capital Gains Tax, supra note 34 , at 88 . 
conferring a special benefit upon those persons who make substantial investments in personal residences.

A specified minimum basis, equal to the estate tax exemption, should be provided to exempt smaller estates from deathtime income taxes; no exemption should be provided for personal residences.

\section{Personal and Housebold Effects Exemption.}

The purpose of a personal and household effects exemption is to eliminate the burdensome task of determining whether or not innumerable and often trivial personal effects have appreciated value, by exempting these "assets" from taxation. Such a provision should also exempt personal assets, such as the family automobile, which have a value over $\$ 1000$ but are unlikely to have any appreciation element. The Treasury proposal permanently exempts all gain or loss on each personal or household item which has a value of less than $\$ 1000$. Assets within this exemption receive a stepped-up basis equal to fair market value. In contrast, the House carryover bill exempts personal and household effects not of "extraordinary value," while the AET recognizes neither gains nor losses on personal and household effects which are worth $\$ 5000$ or less per item and the Senate carryover basis bill contains no exemption whatsoever for personal and household effects. The Treasury exemption was apparently based on the British system of taxation which exempted tangible personal property of $£ 1000$ value or less from capital gains tax ${ }^{37}$ But unlike the Treasury proposal, the British allowed losses on the disposal of personal property of $£ 1000$ or greater value and, to a limited extent, upon losses of chattel worth less than $£ 1000 .^{38}$ This allowance of losses, however, caused considerable difficulty, and is therefore not worth emulating.38

37 In Britain, if two or more assets constitured "a set" of articles the $f_{0} 1000$ limitation applied to the entire set. There were some difficulties in Britain determining whether or not a number of assets constitutes a set. As a general rule, Inland Revenue would assert that a group of assets constitute a set if the value of the assets as a set is greater than the total of the values of the assets taken separately. Inland Revenue officials felt that the most troublesome questions arose with regard to antique furniture and works of art. Practitioners in Britain experienced very few doubtful cases and did not consider this problem to be particularly important.

38 Caprtal Gains Tax, supra note 34, at 28. Under the British system, losses on the disposal of chattels worth less than $£ 1000$ were allowed, recomputed as if the consideration for the disposal had been $£ 1000$. Thus a painting bought for $£ 1,100$ and sold for $£ .850$ would produce an allowable loss of $£ 100$. Id .

39 The Finance Act of 1968 eliminated "wasting assets," which were defined so broadly (the term included tangible movable property with a predictable life of less than 50 years) that it would encompass most personal property, from the capital gains tax unless 
Although the difficulties of administering an exemption for personal and household effects on an item by item basis do not seem overwhelming, an appealing alternative is to exempt a predetermined amount of net gain on all personal and household effects. The appeal of this alternative lies in its easy administration, since it would avoid the complexity of itemizing the gain on all such effects. ${ }^{40}$ However, a sufficiently high exception should be provided to effectively preclude such itemization. In addition, gains on assets transferred by gift should be cumulated with gains on assets transferred at death for this purpose.

An exemption for a substantial amount of gain on personal and household effects, say $\$ 25,000$, should be provided so that these assets are eliminated from the application of the tax. Losses on personal and household effects should not be allowed.

\section{Marital Exclusion}

An exemption for property transferred to the surviving spouse stems from a concern about the burden of the tax particularly since that burden varies according to whether the estate is subject to community property law or common law. Because some assets passing to the surviving spouse may also be subject to estate tax under present law, if gains on assets passing to the surviving spouse are taxed, the burden could be offset by an increased estate tax marital deduction. Under the Treasury proposal, property passing to the surviving spouse would be exempt from tax at the time of the decedent's death, but the decedent's basis would carryover. The carryover basis and AET proposals treat such property no differently from assets transferred to other beneficiaries. Under the pre-1971 British system of capital gains taxation an inter vivos gift of appreciated property to the wife was a taxable event but a transfer at death was not, ${ }^{41}$ and although this treatment of interspousal transfers was generally conceded to be illogical, ${ }^{42}$ it seemed to work fairly well in practice.

the assets were used in a trade or business. Capital Gains $T_{A x}$, supra note 34 , at 29. The best approach is to disallow losses on such non-business assets.

40 Under such a proposal, it would be unnecessary to determine whether a group of assets constituted a "set." It would also be irrelevant if part of a "set" were disposed of during life.

41 Capital Gains Tax, supra note 34, at 15. An asset transferred during life from one spouse to the other was deemed to pass at a value which produced no gain or loss to the transferor. The recipient spouse took the basis and the holding period of the transferor spouse. However, this rule did not apply to interspousal transfers at death.

42 The application of the tax at death is best explained as being a result of the British historical approach of imposing an estate tax on property transferred to a spouse at death. 
The Treasury proposal would involve a considerable amount of administrative complexity since, by according different treatment to transfers to the spouse and transfers to other beneficiaries, it suggests the need for basis reallocations. Furthermore, although it might be possible to provide a procedure which would allow the executor to elect which assets are to pass to the surviving spouse and then to amend the return if the actual disposition does not follow the anticipated pattern, the provisions of state law which give the surviving spouse a right to elect against the will, and in many cases, provide the survivor with a fractional interest in all of the decedent's property, make it quite difficult to know which assets will ultimately pass to the surviving spouse. ${ }^{43}$

In the interest of simplicity, no deathtime exception should be provided for property passing to the surviving spouse and no reallocation of basis should be required. However, an exemption for property transferred between spouses during lifetime is desirable. ${ }^{44}$ In addition, an increased estate tax deduction should be adopted to offset some of the effect of the gains tax.

\section{Life lnsurance}

Under present law, death benefits from life insurance policies are not included in the income of the decedent or his beneficiaries. Neither the Treasury capital gains tax proposal nor the AET proposal would change this rule, and yet the special treatment which it affords insurance proceeds is not only inequitable but it also creates an artificial inducement for investment in life insurance.

Death benefits from life insurance policies are comprised of three elements: (1) the return of the decedent's savings; (2) interest on the

43 The pecuniary marital formula trust would further complicate the matter because under it the amount of property passing to the wife would depend upon the amount of capital gains tax imposed on the decedent's estate, which in turn would be dependent upon the amount of property passing to the wife. Simultaneous equations would be necessary under the Treasury Proposal to effectuate such a trust.

44 The tax exemption of lifetime interspousal transfers seems to offer a reaconable solution to the problem of the inconsistent treatment of the surviving spouse's share of community property. In a community property state, property is automatically divided between the spouses during life. An individual in a common law state could divide his property during life and achieve the same tax treatment afforded to community property. Under this approach, the surviving spouse's share of community property will have a carryover basis on the decedent's death; similarly, property transferred to a spouse during life will have a carryover of basis on the decedent's death. Section 1014(b) (6) of the Internal Revenue Code of 1954, providing that the spouse's share of community property gets a stepped-up basis on the decedent's death, would necessarily be repealed. 
savings; and (3) pure insurance proceeds. The pure insurance proceeds represent payment for protection against the risk of loss due to premature death. The savings element is represented by reserve accumulated out of premium payments which earn interest for the benefit of the insured. The insured's reserve at the end of any period equals premiums $^{45}$ minus the cost of term insurance protection plus interest earned on the remainder. The pure insurance protection afforded by a policy is the difference between the face amount and the reserve.

Both the interest earned on savings accumulated under life insurance policies and the pure insurance proceeds are income in the broad sense, ${ }^{46}$ and although some might consider it overly harsh to impose a tax on the insurance element, any interest earned on the accumulated savings should certainly be taxed in connection with a proposal to tax unrealized appreciation at death, since it is indistinguishable from other forms of capital appreciation. Moreover, the interest element of life insurance proceeds may range from about 12 percent on ordinary life policies to more than 30 percent on single-premium life pohicies. ${ }^{47}$ If such income is not taxed, variable life insurance policies would likely flourish. Thus, at a minimum, interest earned on life insurance policies should be subject to a deathtime income tax.

\section{Transfers to Charity}

Under the Treasury capital gains tax proposal, transfers to public charities would be exempt from tax. In contrast, pursuant to the AET such transfers would be taxed; this in turn would mean that the amount available to the charity as a result of such a transfer would be reduced. The decision whether charitable transfers should be exempt from a deathtime tax on unrealized appreciation necessarily reflects the decisionmaker's personal disposition toward charitable organizations and charitable spending. Under present tax law the donor who gives appreciated property to a public charity by inter vivos transfer may typically take a charitable contributions deduction for the fair market value of the property. ${ }^{48}$ This rule allows the appreciation of the property in the donor's hands to escape taxation. Although this rule has been criticized

45 Net of loading charges.

46 See Goode, Policybolders Interest Income under the Income Tax, 16 VAND. L. REv. 33 (1962).

47 See McLure, The Income Tax Treatment of Interest Earned on Savings in Life Insurance, in Jonxt Economic Commities, The Economics of Federal Subsidy Programs: A Compendium of Papers, 92d Cong., 2d Sess., 370 (July 15, 1972).

48 INT. REv. CODE of 1954, $\$ 170$ (e). 
by tax scholars and reviewed by the Congress over the years, ${ }^{49}$ Congress has generally retained the provision without substantial modification. ${ }^{50}$ Application of a similar rule to property transferred to public charity upon death would not require reallocation of basis nor would it result in other complexities.51 Furthermore, the exemption could be tailored to eliminate most of the incentive for making gifts of low basis assets by allowing only specific bequests to charities and by requiring that gifts include, either in cash or in additional unappreciated property, the amount of tax-savings which would accrue to the estate as a result of making the gift. This, in turn, would eliminate the need for a reallocation of basis. Property transferred to public charities should be held exempt from deathtime income tax. ${ }^{52}$

\section{Generation-Skipping Transfers.}

Under the present estate tax rules, it is possible to avoid application of the estate tax over a number of generations through the use of gen-

49 In 1938 the House of Representatives voted to limit the deductibility of appreciated gifts to charity to the adjusted basis of the property in the hands of the taxpayer. However, the Senate Finance Committee rejected the House proposal, stating:

Representations were made to the Committee by officials of educational and charitable institutions that the effect of such a provision would be to discourage the making of charitable gifts in kind. The Committee believes that charitable gifts generally ought to be encouraged and so has eliminated this provision of the House bill.

S. Rep. No. 15-67, 75th Cong., 3d Sess. 14 (1938).

50 Full deductibility of gifts of appreciated property remained intact until the Tax Reform Act of 1969, which made three changes. First, deductions based on gifts of appreciated property whose sale would have produced ordinary income are limited to the donor's cost basis. Second, deductions for donations of appreciated capital gains property to private nonoperating foundations are reduced by 50 percent of the appreciation element in the value of the gift. Third, the deduction for gifts of tangible personal property whose use is unrelated to the exempt purpose of the charitable donee is reduced by 50 percent of the appreciation element in the value of the gift. A deduction equal to the fair market value of gifts of appreciated securities and real estate to public charities and private operating foundations is still allowed, so long as such gifts do not exceed 30 percent of the taxpayer's adjusted gross income.

51 Evaluation of the propriety of the present rules regarding the income tax treatment of lifetime transfers to charity is beyond the scope of this Article.

52 A similar exemption for transfers of appreciated property to private foundations is not recommended because the present income tax treatment of inter vivos transfers of appreciated property to private foundations is less favorable than the treatment of transfers to public charities. If it is determined that the 1969 Act provisions regulating the conduct and distributions of private foundations prove effective in insuring that foundation funds are used for charitable purposes, the distinction between gifts to private foundations and public charities may no longer be necessary, and an exemption from deathtime tax of gifts to private foundations may be appropriate. 
eration-skipping trusts. ${ }^{53}$ Absent a special provision, a deathtime tax on appreciation could be similarly avoided, although in this context deferral of tax rather than complete avoidance would be the result.

Whereas the AET contains no provision to deal with this problem, the solution recommended by the Treasury proposal is unduly harsh and complicated. In order to prevent generation-skipping, the latter proposal would impose an additional tax upon transferred property on four specified occasions. First, if distribution of the property were made to any person who was more than one degree lower in relation to the transferor, such as a grandson of the transferor, the distribution would be taxed. Second, a tax on appreciation would be imposed upon the death of the last surviving beneficiary in the one-degree group. Third, the tax would be imposed upon distribution to beneficiaries more than 25 years younger than the transferor who are not related to the transferor. Finally, assets held in a trust, which remain undistributed, would be taxed every twenty years.

The Treasury proposal is similar to the capital gains tax on trusts introduced in 1965 in Britain. An analysis of the British experience suggests that the Treasury generation-skipping proposals should not be adopted in toto. Britain's application of the capital gains tax to trusts was the most controversial and administratively complex aspect of that country's capital gains tax. The transfer of property to a trust, disposal of property by the trustee, and termination of a life estate were all treated as taxable events. ${ }^{54}$ Moreover, if there were no life interest in possession, unrealized gains were taxed every 15 years. ${ }^{55}$

53 See Treasury Proposals, supta note 8, at 388-89.

54 The taxation of unrealized gains upon termination of a life interest is consistent with the British estate tax rules. Under these rules, trust property in which the decedent has a life interest is included in his estate.

55 Capital $G_{\text {ains }} T_{A x}$ supra note 34, at 90-98. The specific rules follow:

(a) The transfer of property to a trust (revocable or irrevocable) is treated as a taxable disposal of the entire property even though the settlor has an interest as a beneficiary or as a trustee. Thus, for example, if an individual were to place land in trust retaining a life estate, capital gains tax would be due on the entire increase in value of the land rather than on only the value of the reversionary interest.

(b) Whenever assets leave the trust, the capital gains tax applies. Thus, the capital gains tax applies when any trust assets are actually disposed of by the trustee. Moreover, when any person becomes "absolutely entitled against the trustee" to any part of the trust property, the assets to which he has become absolutely entitled are deemed to be disposed of by the trustee at their market value, and any unreahized gains or losses in these assets are taxed. The phrase "absolutely entit'ed against the trustee" resulted in widespread controversy as to the incidence of the tax. 
The 15-year rule was designed to prevent the practice of avoiding capital gains tax by placing appreciated assets into discretionary or other trusts which, because their continued existence did not depend on the life of any specified person, were of indefinite duration. Private practitioners consider this rule to have been the most unfair and harsh aspect of the capital gains tax. Not the least of the rule's difficulties was that, at the end of each 15-year period, it required a complete valuation of the assets of those trusts to which it applied. Moreover, it is generally conceded that numerous closely-held businesses were forced out of existence because of the imposition of the tax every 15 years. ${ }^{56}$ This deleterious effect resulted because in Britain shares in many closely-

(c) When a life interest in trust property terminates, capital gain tax applies to any unrealized gains: The trustees are deemed to have disposed of and immediately reacquired the trust property at its current market value. However, when a life interest in trust property terminates less than 15 years after an earlier life interest in the trust property lias terminated, there is no deemed disposal as a result of the latter termination, but unrealized gains will be taxed 15 years after the earlier termination. This rule prevents taxation due to the termination of life estates more often than once every 15 years.

(d) If there is no life interest in possession, unrealized gains are taxed on the fifteenth anniversary of the date the trust was formed and at the end of each succeeding period of 15 years.

(e) In the case of charitable trusts, when property ceases to be subject to the charitable trust, unrealized gains are taxed.

The application of these rules may be more readily understood by the following example:

Assume a trust which is established on December 31, 1965, with five life interests terminating as follows:

(a) First interest terminated December 1966.

(b) Second interest terminated December 1970.

(c) Third interest terminates December 1971.

(d) Fourth interest terminates December 1972.

(e) Fifth interest terminates December 1999.

The tax will apply on the following occasions:

(a) December 1966 because of the termination of a life interest.

(b) December 1981, which is 15 years after the previous tax applied and is a deemed termination of a life interest because actual life interests have terminated within the 15-year period.

(c) December 1999, on the termination of a life interest. The termination of life interests in December 1970, 1971 and 1972 do not result in tax because they occur less than 15 years after the December 1966 taxable occasion. (Only where there are no life interests in possession does the tax apply every 15 years.)

56 The application of the tax every 15 years has been avoided to a large degree in Britain through the use of foreign trusts, since nonresident trustees are not liable for the capital gains tax. 
held businesses are placed in trust and there was often no cash available to pay the tax at the expiration of the 15-year period; the problem was aggravated by the high income tax which applied whenever money was paid out of a closely-held business.

Such a rule is also burdensome for trusts comprised primarily of traded securities. The trust investments are likely to change at least every 15 to 20 years, particularly if the trust is administered by a professional fiduciary. Since a tax will be imposed, in these cases, at the time the investment change is made, the periodic tax is not necessary and will only serve to complicate trust administration. One alternative to the Treasury generation-skipping proposal is to alter the Rnle against Perpetuities to provide a limitation on the length of time a trust will be recognized as a separate entity for tax purposes. In Britain the rule has been shortened by statute to 80 years. Other alternatives may be developed in connection with the administration of the estate tax since generation-skipping has a greater impact in that area.

If a workable means for eliminating the generation-skipping problem is developed in conjunction with the estate tax, the solution should be adapted to the capital gains tax. ${ }^{57}$

\section{Losses}

The Treasury capital gains tax proposal recognizes capital losses and applies the normal income tax rules to them. Losses sustained on sales or exchanges during the last year of the decedent's life and any capital

57 Under the estate tax, outright transfers which skip a generation should not be taxed. Reform efforts should concentrate only on the true abuses-transfers which permit the intervening generation to enjoy the property during his lifetime without estate tax at the time of his death or trusts that skip more than one generation. Thus, reforms should impose an additional tax at the time of the death of the beneficiary, for example, in a trust which skips only one generation but gives the income beneficiary some potential interest in corpus, as where there is a right to invade corpus on his behalf, or a special power of appointment. A rule can be devised to determine his potential interest in the corpus in such cases, and he can properly be taxed as if there were a transfer from him to the succeeding beneficiaries.

With respect to the actual mechanics of collecting the tax, consideration should be given to the British system. In Britain, the capital gains tax on trust property is payable out of the trust property, and the trustee is liable for the tax, though his liability is nor personal. If the trustee does not pay the tax and the trust assets have been transferred to a beneficiary, a lien follows the trust property and Inland Revenue may collect the tax (or an amount proportional to the beneficiary's share) from the beneficiary as the representative of the trustee. This collection method has worked well and deserves consideration in conjunction with an estate tax generation-skipping proposal as well as a gains-atdeath proposal. 
losses carried forward from previous years would be deductible on the final tax return. The proposal also contains a special rule that unused capital losses could be used to offset capital gains of the decedent in his three prior taxable years; if some capital losses are still unused, they may be carried back to offset ordinary income in the decedent's last four taxable years. ${ }^{58}$ However, the tax saving resulting from allowing such losses may not exceed twenty-five percent of the amount of ordinary income offset. Whether or not this limitation is necessary depends on the applicability of the $\$ 50,000$ restriction on the use of the 25 percent alternate capital gains rate introduced by the 1969 Act. If that restriction were to apply to capital gains at death, the limitation in the Treasury proposal would be superfluous. Use of the 25 percent rate on the first $\$ 50,000$ of capital gains is not sufficient to warrant this tax benefit limitation. On the other hand, if the $\$ 50,000$ restriction is not applied to capital gains at death, this limitation would be proper.

In the interest of simplicity the AET allows no tax savings from a net loss. This provision is too inequitable. An estate tax reduction based on the amount of the loss multiplied by the flat AET rate should be allowed. The Senate proposal is also inequitable. The carryover basis concept underlying that proposal requires that the beneficiary be taxed on the decedent's gains. Under the House bill the carryover basis would apply regardless of whether the property in an estate has increased or decreased in value; thus the beneficiary would be allowed the decedent's losses. Under the Senate bill, however, the basis which is carried over is the value of an estate's assets computed for estate tax purposes. $^{59}$ Since this value takes into account ouly appreciation and not depreciation, the beneficiary is effectively denied the decedent's losses. The Senate provision should be brought into line with the House proposal, particularly since in the case of deathtime transfers deliberate shifting of losses among taxpayers is unlikely.

Thus any deathtime tax scheme should allow net losses to be offset either against estate tax or against income tax of prior years.

58 The special rule of the Treasury proposal which provides that capital losses are deductible only to the same extent that capital gains were included in ordinary income is no longer necessary after the amendments of the 1969 Act providing that only $50 \%$ of the net long-term capital losses in excess of net short-term gains may be deducted from ordinary income. INT. REv. CoDE of $1954, \$ 1211$ (b). The provision that only $\$ 1000$ of ordinary income can be offset by capital losses also should not apply to deathtime capital losses.

59 The gift tax rule is similar; the gift tax basis for determining lasses is the fair market value at the time of the gift. 


\section{Rate of $\operatorname{Tax}$}

The Treasury proposal maintains the regular capital gains rates. When the Treasury proposal was published, the top capital gains rate was 25 percent. The 1969 Tax Reform Act has since limited the use of the 25 percent alternative capital gains rate to the first $\$ 50,000$ of longterm capital gains and imposes a higher rate thereafter. The question therefore arises whether the $\$ 50,000$ limitation should be applied to assets included in the decedent's final income tax return only by reason of his deatl. The 25 percent maximum rate was traditionally justified primarily on the ground that it provided an incentive for making capital investments; this rationale does not logically support a limited capital gains tax at death. On the other hand, the argument traditionally advanced to justify limiting the use of the alternative rate-that the limitation restores the eroding progressivity of the income tax-probably does not apply in the context of realization at death either. If unlimited application of the maximum 25 percent rate is not permitted, special averaging rules, similar to those enacted in the 1969 Act, seem necessary.

The Treasury proposal's treatment of ordinary income and hybrid assets is also worth consideration. Generally, in the case of assets such as inventory, whicl would produce ordinary income when sold, the proposal would apply the ordinary income rates. In the case of assets such as depreciable real or personal property, on which the gain would be taxed partly as ordinary income and partly as capital gain, the proposal would apply the rules for determining gain which would have applied had the decedent sold the asset on the day of death. Whether the gain will be ordinary income or capital gain would depend on the rules generally applicable to the disposition of such assets; in addition, ordinary losses would be recognized. Assets on which gain would be treated as ordinary income only because of an insufficient lolding period and installment obligations and options ${ }^{60}$ would receive long-term capital gain treatment when taxed in the final return of the decedent. Although according tax treatment based on the nature of the asset is consistent with the general theory of the realization at death proposal, it may produce an unacceptable amount of complexity, particularly when coupled with the provisions of the Treasury scheme calling for reallocation of basis and special averaging. ${ }^{61}$

60 Stock options would be an example of this kind of asset.

6t See Treasury Proposals, supta note 8, at 339. 
The Treasury proposal would also repeal section 691 of the Internal Revenue Code which provides that all items of income that were earned or realized by the decedent prior to his death but that were not reportable in the decedent's final return must be reported as income by the decedent's successor in interest at the time of receipt. ${ }^{62}$ Under present law such income is treated by the recipient in the same manner ${ }^{63}$ as it would have been treated by the decedent. The income-producing items, which are included in the decedent's gross estate, do not receive a stepped-up basis, but a portion of the estate tax attributable to each item is allowed the successor as a deduction when he computes the income tax on the item. In contrast, under the Treasury proposal this income would be taxed at death.

The AET plan achieves the simplest rate structure of all the proposals by applying a flat 14 percent rate to net appreciation in the estate. ${ }^{64}$ If an increase in basis is allowed to eliminate the double tax, the lifetime capital gains rates would presumably apply. The AET proposal does not distinguish between ordinary income assets and assets which would produce capital gains. It also retains the provisions of section 691, principally because of the difficulties of valuing certain items of 691 income such as patent and copyright royalties and income from phantom stock plans.

The simplicity of the AET plan makes it preferable to the Treasury proposal, even though it treats ordinary income assets more favorably at death than if sold during life and may treat certain section 691 income more favorably than capital gain income. In addition, applying a relatively low maximum rate to all appreciation eliminates any need for averaging rules.

Under a deathtime tax a maximum rate of 25 percent should be applied to total net appreciation of all assets including assets which, if sold, would produce gain taxable at ordinary income rates, and the present rules governing section 691 income should be retained.

\section{Effective Date}

Both the AET and the Treasury proposals contain provisions which would exempt from the deathtime tax gains accrued prior to a given

62 See INT. REv. Code of 1954, $\$ 691$.

63 L.e., as ordinary income or capital gain.

64 The rate is based upon the complement of the highest estate tax rate, which is reduced to $60 \%$ under the proposal, and the highest capital gains tax rate, and is lower than the capital gains rate because of the "double tax" element. 
"start-up" date. Under the AET plan, both gains and losses are computed as of the new valuation date. Under the Treasury proposal the taxpayer would have the option, in computing gain on property-other than ordinary income items-acquired before the date of enactment, of using as his basis either the adjusted basis of the property computed under existing law or the value of the property on the date of the enactment; ${ }^{65}$ for the purposes of computing losses on transferred property acquired by the decedent before the date of enactment, the basis would be the lower of these two values. In contrast, neither the House nor the Senate carryover basis bills provide a new valuation date; the carryover basis would apply to the estates of all decedents dying after enactment. The latter proposals require that the decedent have adequate records of basis, but ignore the fact that at present persons cannot be expected to have such records since they are not required under current law for assets held until death. Their failure to deal with this problem is clearly a major inadequacy.

The AET and Treasury provisions which would exempt from tax all unrealized appreciation accruing prior to the new valuation date would be an equitable way of phasing in either reform proposal. However, there are two alternatives to this method, both of which would expand revenues from the new tax liability. The first is a delayed effective date provision. Such a provision would allow the taxpayer a period of time in which to adjust to the new rules but ultimately would tax unrealized appreciation that accrued prior to enactment. It might provide, for example, that the new tax scheme would apply ouly to decedents who die more than three years after the date of enactment, thus giving all persons three years to modify their estate plans.

The second alternative would be to phase the tax in over a certain period of time. A phase-in provision might exempt persons dying during the first year after enactment from the realization-at-death proposal, while requiring tax payments by persons dying during the second and each succeeding year after enactment based upon incremental portions of the gain realized upon death. Persons dying in the second year could be taxed on one-tenth of the gain; those dying during the third year, on two-tenths of the gain, and so on until the tenth year when the provision would be fully effective. Although this alternative might avoid certain administrative and valuation problems spawned by

65 This would be adjusted under present law for any changes occurring after that date. Gain on ordinary income assets would be determined from adjusted basis. See TrEasurY Proposals, supra note 8, at 351. 
the AET and Treasury proposals, its weakness is in assuming that a deceased person will have kept records of his basis, an assumption which is unwarranted.

The British experience is helpful in evaluating alternative proposals for a new valuation date. When the capital gains tax was introduced in Britain, only gains accruing after a new valuation date were to be taxed. The tax distinguished marketable securities and developed land from other assets. To compute the amount of gain on the former, the actual value on April 6, 1965 was generally used. However, if the actual gain on the sale of an asset was less than the gain with reference to the value of the asset on April 6,1965, only the smaller gain was taxable. Similarly, if there was a loss based on actual cost which was less than the loss since April 6,1965, only the smaller loss was allowed. In cases where there was an actual gain but a loss based on the valuation date value, or vice-versa, neither a gain nor a loss was recognized.

With respect to other assets such as shares in a closely-held corporation or unimproved land, the English system used a "time-apportionment" formula to allocate the entire gain on an asset over the period since its acquisition by a taxpayer in order to determine what portion of the gain was realized after April 6, $1965{ }^{66}$ The time-allocation formula, however, is obviously arbitrary. Moreover, it is unworkable unless knowledge of the actual basis and date of acquisition of each asset is available. These two facts compelled British lawmakers to allow the taxpayer to elect to have the taxable gain on these assets determined by reference to the actual market value on April 6, 1965 under the same rules which apply to quoted securities. Such an election was irrevocable. ${ }^{67}$

Nevertheless, the time-apportionment formula, at first blush, seems to be a useful technique. Inland Revenue, the British agency corresponding to the IRS, considered it necessary because it felt it did not

66 If, for example, unquoted shares were acquired on April 6, 1962 (three years before April 6, 1965), and disposed of with a $\$ 1000$ gain on April 6, 1970 (five years after April $6,1965)$, taxable gain would be $\$ 625$, i.e., five-eighths of the total $\$ 1000$ gain. Assets which were acquired more than twenty years prior to April 6,1945, were deemed to have been acquired on April 6, 1945, for purposes of applying the time-apportionment formula.

67 Under the Finance Act of 1968 , an additional election was provided with respect to quoted stocks and bonds to allow persons to elect to use the actual value as of April 6,1965 , on all disposals without regard to whether the actual gains were less or losses were greater. For the purposes of this election, stocks and bonds were grouped into two classes: (1) common stocks and (2) fixed interest stocks and bonds. The election was made with respect to each of these classes and applied to all assets in the class held on April 6,1965. The election was also irrevocable. 
have sufficient personnel to valuate all assets, particularly unlisted stocks, as of the new valuation date. The time-apportionment method has been used in many cases involving unlisted stocks, and Inland Revenue has indeed saved some administrative costs. However the election provision, implemented primarily because of equitable considerations, undermined the anticipated savings since sophisticated practitioners tended to elect the method which promised to save most tax; this practice, in turn, required double-computation of the basis.

Furthermore, the irrevocability of the election provision made it difficult to administer equitably. Generally, practitioners were required to make the election while they were still unaware of factors which Inland Revenue would consider important in valuating assets. When a wrong assumption was made and it later developed that the unelected method of valuation would have been more favorable, many taxpayers attempted to revoke the election on the grounds that they had been unaware of all the relevant facts and circumstances when they made their election. Inland Revenue provoked considerable controversy when it began allowing revocations in cases where there was "a fundamental misapprehension as to the basis of valuation which will be used." In general, the time consumed in resolving disputes over unwise elections greatly reduced the savings in administrative and manpower which the time-apportionment technique was meant to produce.

Perhaps the clearest lesson from the British experience is the need to apply fixed rules with as few options as possible. Although a mandatory time-apportionment method of valuation for unquoted securities and other assets would appear to eliminate the need for actual valuation of a great number of difficult-to-valuate assets, the time-apportionment formula has proved unworkable without an optional valuation method; this, in turn, has undermined the rationale for such a formula. This suggests that requiring valuation of all assets on a specified valuation date is the better approach. If using actual basis would prove more advantageous to the taxpayer, he might be given the option of computing gains or losses using actual basis, but the burden should clearly be on the taxpayer to determine that actual basis is more beneficial.

As stated previously, under the 1968 Treasury proposals gains would be computed using, at the taxpayer's option, either adjusted basis or value as of the new valuation date, while losses would be computed using the lower of actual basis or valuation date value. This latter dichotomous provision is unnecessary. In the interests of simplicity and efficient admimistration it would be preferable to bind the IRS 
to one value for the purposes of determining losses-the value on the valuation date-while allowing taxpayers the option of electing to use actual basis in cases where it stood to their advantage.

Appraising assets as of a new valuation date will, of course, result in additional administrative costs. Although assets are currently valued for estate and gift tax purposes, the taxpayer's basis in assets transferred at death is not relevant under present law. However, the fact that valuation date appraisals add complexity to an already involved area of the tax law may be partially offset by the fact that such appraisals could have a beneficial effect on the administration of the estate tax. In determining the estate tax government personnel ordinarily argue for high values and taxpayers argue for low valuations. In appraising assets on the valuation date for the purposes of the capital gains tax, the parties would change places-the government arguing for a low basis and the taxpayer for high. This might induce the parties to be more sympathetic to each other's arguments and estimated valuations, with the result that disputes over the value of particular assets might become somewhat easier to resolve.

Even so, the burden of valuing every asset, other than personal and household effects, as of the new valuation date should not be minimized. This is one cost of taxing gains at death. The valuation of assets such as partnership interests, shares in closely-held corporations and assets in a sole proprietorship will be expensive; it will be burdensome to taxpayers and will undoubtedly increase administrative costs to the Internal Revenue Service. Nevertheless, a new valuation date should be applied in computing gains and losses.

\section{Special Rules for Illiquid Estates}

Beneficiaries of estates composed principally of illiquid assets such as farms or family businesses will object to any change in present law. While none of the proposals under consideration deal directly with these assets, it has been suggested that interests in closely-held businesses, including farms, should be exempted from a deathtime tax on uurealized appreciation. If a broad exception of this type is adopted, a capital gains tax at death will have very uneven application. Generous extended payment rules could avoid this inequity.

An exemption for closely-held businesses would create considerable technical difficulty. Presumably the exception would cover unincorporated businesses and partnerships, as well as closely-held corporations. But numerous rules would be necessary to govern whether particular 
corporations qualified for this exemption. For example, attribution rules which take voting power into account in addition to value would be necessary to effectuate determinations of stock ownership. Other rules might be necessary to require that a corporation or partnership be engaged in the active conduct of at least one trade or business or to provide that, if sufficient assets were devoted to the business, all assets would fall within the exception. On the other hand, it might be desirable to develop rules allowing an exemption only for assets used in the trade or business as opposed to assets held for investment. In addition, a ceiling on the value of assets to be exempted should be considered. If a flat ceiling, say $\$ 1,000,000$, were selected, a problem of fairness would result for businesses just over $\$ 1,000,000$ unless a universal exemption were provided for the first $\$ 1,000,000$ of value in any business. ${ }^{88}$ If the latter rule were adopted, the exemption would become very general in application and the impact of the income tax at death would be further mitigated. In addition, it would of course be necessary to integrate this exemption with other provisions; for example, the $\$ 60,000$ basic exemption could be applied against the family business before the special exemption was brought into operation.

If a small business exception were provided, carryover basis would probably apply with respect to the exempted assets. For an estate consisting largely of depreciable and inventory assets, carryover basis may be nuore severe than a deathtime capital gains tax. An estate consisting entirely of buildings, for example, would, at the cost of a capital gains tax, obtain a new basis for depreciation. The current discounted value of future tax savings at ordinary income rates which would result from the new basis is likely to be similar to the cost of a capital gains tax at death. If, as suggested earlier, a maximum 25 percent rate is adopted to apply to ordinary income assets as well as capital gain assets, the average taxpayer would not likely gain from a rule providing carryover basis on business assets.

Generous extended payment rules are preferable to an exemption. Under such provisions, the tax would not diminish needed working capital, but the taxpayer could pay interest on the amount of the tax he defers. These provisions could require the government to partially share the risk of decline in business value; if the worth of the estate declines by the time at which the tax is due, a portion of the tax could

68 The problem would be that a business which contained assets with a value of $\$ 1,000,000$ or less would be exempt from imposition of the tax, but an additional $\$ 1$ in value could trigger a $\$ 250,000$ increase in tax. 
be forgiven. Such extended payment rules should be provided in lieu of an exemption for family businesses or farms.

\section{Conclusion}

Present law affords taxpayers an opportunity to avoid income tax by holding assets until death. Unlike other exemptions from tax such as the interest on state and local bonds this rule is not designed to further governmental objectives. Moreover, the refusal to reform existing tax law to eliminate the exclusion for appreciated assets transferred at death cannot be justified on the ground that it promotes tax relief; such a proposal could contain a provision insuring that any change would apply only to upper-income taxpayers. Reform would produce greater equity, would secure additional revenue which could provide income or estate tax relief or finance government programs, and would reduce the "lock-in" effect of present law. Reform should also prevent the inequity of double-taxation. On balance, the advantages of a tax on appreciation at death are greater than the advantages of carryover basis, but carryover basis is preferable to existing law. The AET, with the suggested modifications, is an acceptable alternative. However, regardless of which reform is adopted Congress must be careful not to reduce the potential benefits of the reform by enacting a complicated and unwieldy set of rules. 